\title{
Are the Key Persons in Companies Also Their Key Assets? Evidence from a Transition Economy
}

\author{
Katarzyna Byrka-Kita, Mateusz Czerwinski, Renata Gola
}

\author{
University of Szczecin \\ Mickiewicza 64, 71101 Szczecin, Poland \\ E-mail.katarzyna.byrka-kita@usz.edu.pl; mateusz.czerwinski@usz.edu.pl; renata.gola38@gmail.com
}

cross $^{\text {ref }}$ http://dx.doi.org/10.5755/j01.ee.31.5.23242

\begin{abstract}
This study examines how published information about the death of a key person in a company has affected its market valuation as listed on the Warsaw Stock Exchange during the period 2005-2017. We find that investors reacted negatively and statistically significantly to information about the death of a key person. Furthermore we confirmed a positive reaction to the loss of a so-called "entrenched CEO". The same pattern of investor reaction is observed in more mature markets. These findings seem to support the upper echelons theory and entrenchment hypothesis. The obtained results not only contribute to the development of the theory, but also have significant practical implications. Primarily, investors should take into account such events when they are implementing investment strategies. Further, these results suggest that Polish firms need to undertake more formal succession planning for their executives.
\end{abstract}

Keywords: Top Management Turnover; Organizational Change; Upper Echelons Theory; Agency Theory; Entrenchment Hypothesis; Warsaw Stock Exchange.

\section{Introduction}

The upper echelons theory (Hambrick \& Mason, 1984) argues that the characteristics of top management teams do influence organizational outcomes such as strategies and effectiveness. There are numerous empirical analyses providing evidence of the significance of the quality of leadership and of the personality, education and experience of a leader (Hambrick \& Mason, 1984; Davidson et al., 1990; Denis \& Denis, 1995; Farrell \& Hersch, 2005; Pundziene \& Duobiene, 2006; Buoziute-Rafanaviciene et al., 2009; Campbell \& Vera, 2010; Nguyen \& Nielsen, 2010; Kaplan et al., 2012; Gomulya \& Boeker, 2014). However, the body of research on executive turnover typically concentrates on the Chief Executive Officer (CEO). Very little attention has been devoted to the other board members that are likely to influence the market value of the company. In order to develop research on the strategic changes induced by top management turnover, we created a dataset that includes departures of not only CEOs, but also other members of the management board, members of the supervisory board and dominant shareholders.

According to Ocasio (1994), following the power circulation theory of control introduced by Mosca, Pareto, and Michels and adapted by Selznick (1957), due to increased technical and political obsolescence long-tenured CEOs are less likely to undertake organizational change. Furthermore, according to agency theory, if a deep-rooted key person leaves an organization, the stock price reaction should be positive where investors consider that person ineffective. We complemented this thread of research by exploring departures due to death. According to Lee et al. (2020), using the sudden death of a CEO as an empirical setting is advantageous as such departures can be considered random, which mitigates a possible endogeneity concern. Similarly, departure timing is chosen exogenously.

Empirical findings on market reaction mostly focus on developed markets or the US market. The number of studies concerning Europe or emerging markets (focused mainly on Asia) is substantially smaller. In the Indonesian market Setiawan et al. (2011) proved a positive and statistically significant market reaction in the case of a sudden resignation. In the Chinese market, shareholder reaction was positive for enterprises owned by the central government (Pessarossi \& Weil, 2013). Other research on developing Asian markets concerned a host of other aspects of CEO succession (Huang et al., 2008; Ishak \& Latif, 2013; Ismail \& Manaf, 2016).

In countries with an Anglo-Saxon system of corporate governance and with certain cultural determinants, there is a preference for the nominations of charismatic personalities to the highest managerial positions (Elsaid et al., 2011, Hamori \& Koyuncu, 2015). The CEO of a company is expected to have not only a media presence, but to provide a personal narrative and to have an open attitude to dialogue (Malmendier \& Tate, 2009). As a result, some investors do not identify with the companies themselves but with the people or teams perceived to have key positions within the companies. The presence of such people in a company is treated as a way of minimizing business risk as well as securing future ownership rewards for the investors and other stakeholders. Meanwhile, in public companies in Poland, as in Germany, there is a two-tier and collegial system of corporate governance, where leaders do not expose themselves publicly. As an example, the owners and managers of giant companies such as Aldi and Lidl make significant contributions to organizational change and the market values of these companies, yet they are not personally 
brought to the fore. As such, it becomes doubtful whether in such conditions the shareholders would notice the loss of a key person, which contradicts the upper echelons theory (Hambrick \& Mason, 1984), suggesting that the performance of an organization reflects the characteristics of its top executives. In light of the above, the purpose of our research was to examine if published information about the death of a key person in a company has affected its market valuation. We ask the question: whether CEOs, other members of the management board, members of the supervisory board and the dominant shareholders are key assets in transition economies such as Poland? Do they really influence the organisational values and trigger organisational changes from the point of view of the investors? Our study makes several important contributions to literature on organizational change, CEO turnover, corporate governance and shareholder value. First, we contribute to entrepreneurship literature in general - and to top management literature in particular (Bennedsen et al., 2007; Lee et al., 2020). We provide strong evidence for the empirically underexplored link between the general capabilities of the management staff and a company's market value. Such a research problem fills the research gap because it concerns the East European post-communist market, which is much less explored than developed markets. Comparable studies referring to the markets of Central and Eastern Europe have not been identified. Second, we add to corporate governance literature by estimating the value of top managerial talent. Following Dherment-Ferere \& Renneboog (2002), we analyse the difference between the market response to age-related retirements and unexpected deaths of key persons. Our study aims to shed light on the question: Does the unexpected death of a key person always entail a loss of human capital to the firm? In our opinion, the results presented here contribute to literature on the theory of the market valuation of companies in terms of a "key person discount". Furthermore we contribute to studies on managerial entrenchment and its implications for corporate governance. According to the agency theory, CEOs are selfinterested, risk averse and maximize their benefits to the detriment of corporate value (Jensen \& Meckling, 1976). Weisbach (1988) claims that :"Managerial entrenchment occurs when managers gain so much power that they are able to use the firm to further their own interests rather than the interests of shareholders". Shleifer \& Vishny (1989) observe that entrenched managers often engage in selfserving actions at the shareholders' expense. This paper broadens the knowledge by showing that CEO entrenchment in transition economies has a significant effect on shareholder wealth. Finally, we contribute to literature that studies the relationship between the equity participation of a key person and stock performance. In our research, we deliver evidence for the empirically underexplored hypothesis that the holdings of a departing key person is significantly related to shareholder wealth. Previous studies typically concentrate on the death of the CEO (Johnson et al. 1985; Worrell et al., 1993; DhermentFerere \& Renneboog, 2002; Bennedsen et al., 2007; Nguyen \& Nielsen, 2010; Salas, 2010; Nguyen \& Nielsen, 2014; Brochet et al., 2015; Jenter et al., 2017). We also considered other members of the management board, members of the supervisory board and the dominant shareholders. Assuming that key person deaths are not necessarily accompanied by poor financial performance, as in most managerial turnover events, our study sheds light on the value of key persons, and not only in underperforming companies.

In order to investigate how the news of the death of a key person in a company affects the company's market valuation, we use information about companies listed on the Warsaw Stock Exchange (WSE) during the period 20052017. It is our understanding that key people include CEOs and other members of the management board of a company, members of the supervisory board and the key shareholders, whose involvement can bring additional economic benefits. In this study, we used the methodology of event studies, measures of descriptive statistics and econometric modelling. The problem associated with researching this type of phenomenon is that the information needs to be collected manually, making the process extremely tedious and labour-intensive. The sample used in this study included the sudden departures of 81 key persons. We modified the standard methodology by introducing a reaction day, which then was used to measure abnormal rates of return, which may have been biased due to differences between the date of the actual event and the date of the press release.

This paper is divided into five parts. The introduction is followed by a review of literature, and the research hypotheses are formulated against this background. We then describe construction of our sample and research methodology, report the results of our study, and present our discussion and conclusions.

\section{Literature Review and Setting out Hypotheses}

The loss of a key person in a company can be perceived as the cause of a decrease of the value of intellectual capital, and a factor that increases the risk of deterioration in the company's performance and a decrease of its share value. The results of most empirical research indicate the existence of a negative correlation between the sudden departure of a key person and the company's market valuation (see Table 1).

Bennedsen et al. (2007) investigated the value of top managerial talent in the context of the death of a key person and also in the context of the death of an immediate family member of a key person. The analysis showed that the death of a CEO was strongly correlated with a drop in operating performance results and declines in asset growth and sales growth. The death of an immediate family member of a CEO had a significantly negative impact on company performance. However, the death of a board member did not have a significant impact on a company's prospects. Similar research areas have been covered by Nguyen \& Nielsen (2014), Betzer et al. (2020) and Zhang (2015). DhermentFerere \& Renneboog (2002) expanded the scope of changes in the circumstances of company management by taking into account different types of management turnover, such as forced resignations, voluntary departures and age-related retirements. Brochet et al. (2015) used the event of a death in order to solve the endogeneity problem, which is a significant limitation in the application of the methodology of event studies. 
The research cited above proves that top management can determine, significantly, the level of shareholder wealth, but it does not prove that all top managers are equally important from a company perspective. In a two-tier system of corporate governance where leaders do not make themselves as visible as in the Anglo-Saxon system, the skills of the other members of the management board, the supervisory board and the dominant shareholders may affect stock returns. To apply the view of the upper echelon theory, consequently we hypothesize.

H1: Investor reactions to the news of the death of a key person in companies listed on the WSE are negative.

Table 1

Impact of the Loss of a Key Person on the Market Valuation of a Listed Company - Literature Review

\begin{tabular}{|c|c|c|c|c|c|}
\hline Reference & $\begin{array}{c}\text { Research } \\
\text { period }\end{array}$ & $\begin{array}{c}\text { Size of } \\
\text { investigated } \\
\text { population } \\
\end{array}$ & $\begin{array}{c}\text { Observation } \\
\text { window, in } \\
\text { days } \\
\end{array}$ & $\begin{array}{c}\text { Measure of } \\
\text { abnormal rate of } \\
\text { return } \\
\end{array}$ & Results \\
\hline Slovin \& Sushka (1993) & $1973-1989$ & 85 & {$[-1,0]$} & CAR & Positive impact \\
\hline $\begin{array}{l}\text { Dherment-Ferere \& Renneboog } \\
\text { (2002) }\end{array}$ & 1988-1992 & 277 & {$[-5,+5]$} & CAR & $\begin{array}{l}\text { Negative impact, except for } \\
\text { voluntary resignation }\end{array}$ \\
\hline Bennedsen et al. (2007) & 1994-2002 & 1476 & {$[-4,+4]$} & CAR & Negative impact \\
\hline Nguyen \& Nielsen (2010) & 1994-2007 & 229 & {$[-5,+5]$} & CAR & Negative impact \\
\hline Salas (2010) & $1972-2005$ & 184 & {$[-10,+10]$} & CAR & $\begin{array}{l}\text { Negative impact, except for } \\
\text { entrenched CEOs }\end{array}$ \\
\hline Nguyen \& Nielsen (2014) & 1991-2008 & 149 & {$[-1,+1]$} & CAR & Negative impact \\
\hline Brochet et al. (2015) & 1991-2012 & 80 & {$[-1,+1]$} & CAR & $\begin{array}{l}\text { Positive impact for an expected } \\
\text { death and entrenched CEOs; } \\
\text { negative impact for young CEOs } \\
\text { and short-tenured CEOs }\end{array}$ \\
\hline Zhang (2015) & $1980-2013$ & 22 & {$[-2,+3]$} & CAR & Negative impact \\
\hline Jenter et al. (2017) & 1980-2012 & 458 & $\begin{array}{c}{[-2,+5]} \\
{[-30,+5]}\end{array}$ & $\begin{array}{c}\text { CAR_MM; } \\
\text { CAR_MAR;BHAR, } \\
\text { sudden death; } \\
\text { BHAR, slow death }\end{array}$ & $\begin{array}{l}\text { Positive impact for entrenched } \\
\text { CEOs; negative impact for } \\
\text { young CEOs }\end{array}$ \\
\hline Betzer et al. (2020) & $1980-2012$ & 255 & {$[-1,+1]$} & CAR & Negative impact \\
\hline
\end{tabular}

Notes: SCAR, standardised cumulative abnormal return; CAR_MM, cumulative abnormal return - market model; CAR_MAR, cumulative abnormal returns as the sum of market-adjusted excess returns; BHAR, buy-and-hold abnormal return.

Succession planning is an extremely rare phenomenon in Poland - in reality, in Poland, CEOs change unexpectedly. This applies to both dismissals and unforeseen events such as a death. The absence of a forward-looking and clear succession policy in listed companies is a problem. The lack of a prepared successor creates anxiety for shareholders. The study by DhermentFerere \& Renneboog (2002) is one of a few to include death and age-related retirement in the investigated population. Their research proves the existence of negative values of abnormal rates of return for both these events (death and age-related retirement). Although the negative results for the death of a key person can be rationally substantiated and predicted, it is questionable whether age-related retirements have similar effects. The assumption is that the retirement of an elderly key person should not be surprising, because of their age, and that this event should not trigger a reaction by shareholders. Based on Bennedsen et al. (2007), which concluded that death is a sudden and tragic event causing shock and greatest loss of value in the form of a key person discount, we hypothesise:

H2: Investor reactions to the news of the death of a key person are more negative than in the event of an agerelated retirement.

The occurrence of negative abnormal rates of return accompanying a death raises another doubt. As assumed, in Hypothesis 1, according to the upper echelon theory, the reaction should be negative and, as a consequence, we should see a drop in the company's value. However, would it be possible that, in extraordinary circumstances, shareholders might react positively to the loss of a key person? Salas (2010) makes this point in examining investor reactions when the death removes an ineffective and entrenched executive. He proved that the entrenchment of an executive in a company on average costs 5-7\% of the value of the company's capitalization. A positive reaction by shareholders to the news of a death proves that in the shareholders' opinion the supervisory board should have made some staff changes a long time before. The findings suggest that a sudden death removes a blockage that might have been restricting a takeover of power in the company. Similar research was carried out by Jenter et al. (2017), who concluded that the impact of the loss of a key person on the market valuation of a listed company is positive for entrenched CEOs and negative for young CEOs. The entrenchment hypothesis taken from agency literature is particularly interesting as it is open to debate. On one hand, entrenchment appears to have a negative impact on company performance, while on the other hand, a wellestablished CEO might have extraordinary knowledge of the industry and can determine a company's success. To apply the view of the entrenchment hypothesis, we consequently hypothesise:

H3: Investor reactions to the news of the death of a key person are more positive when that key person was entrenched.

Currently, a factor that significantly affects a company's valuation is the human capital, which includes not only management staff but also the owners of significant holdings. The knowledge, experience and education of these investors can be very valuable with regards to the management of the company. News of the death of Steve Jobs drove the Apple share price down more than 5\% in the Frankfurt Stock Exchange. Lee et al. (2020) studied a slightly different phenomenon - i.e. the relationship between founder CEOs and innovation in public companies. They 
find that the company's innovation performance deteriorates after a founder CEO death. Literature emphasizes just senior executive deaths (Dherment-Ferere \& Renneboog, 2002; Salas, 2010; Nguyen \& Nielsen, 2014), not key persons who had significant holdings in the company. There are no comprehensive studies which specifically examine the valuation effects of sudden death in the case of key persons who are also shareholders. We argue that their ownership stake influences engagement in the company's operations or monitoring, and ultimately the company's market value. Consequently, we hypothesize:

H4: Investor reactions to the news of the death of a key person are greater in line with the equity participation of that key person in the company.

\section{Methodology}

Selection of Announcements. The database that was created to verify the hypotheses set out in this paper was developed by the authors from scratch and is a unique source of information about the Polish capital market. The sample comprises events that include the death and old-age retirement of members of the managing board, members of the supervisory board and significant shareholders in companies listed on the main market of the WSE for the period 2005-2017. The list of events was drawn up on the basis of official stock exchange releases (regulatory announcements). The calendar of events available on the website of the Polish Press Agency was used for this purpose, and was searched using key words such as "death", "deceased" and "departed". Ultimately, the research sample included 81 cases of departures of key persons due to death or old-age retirement. The total number of deaths observed was 56 with 25 cases of retirement. The reason for the smaller number of retirements might be that companies often do not specify the reasons for a key person leaving the company. Sometimes "retirement" is described as "resignation". Figure 1 presents the distribution of the number of events over time broken down by the circumstances of the loss of the key person.
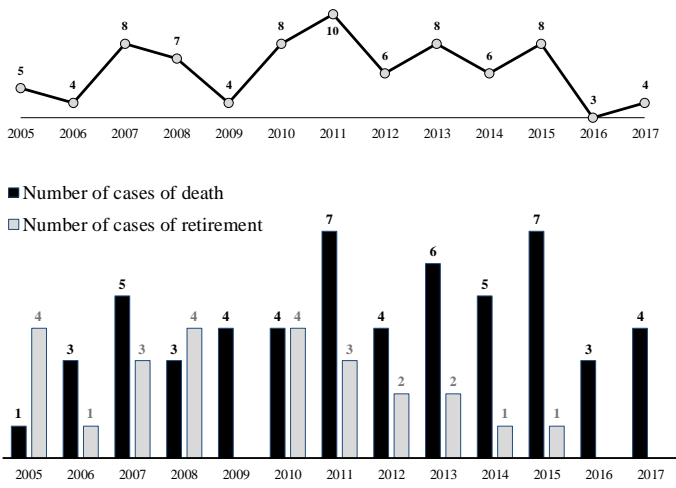

Figure 1. Number of Observations by the Type of Event

A lot of information was collected about each event. Most events included in the research sample concerned

\footnotetext{
${ }^{1}$ Similar to the research of Gurgul et al. (2012) and Daszynska-Zygadlo et al. (2014) it was assumed that there are two categories of investors. One group consists of better-informed people, who on an ongoing basis collect and analyze information that may have an indirect or direct impact on the company, and other investors, who learn about the events only after official
}

members of the supervisory board $(51.85 \%)$. Only eight cases $(9.88 \%)$ were events concerning CEOs. In the analysed research sample, the size of the supervisory board was, on average, 6.64 people while the size of the management board was 4.03 people. The number of years, on average, that a key person holds a position in a company was close to five years, and the average age for departure was 58. Almost $90 \%$ of events concerned people who were not company founders. The entire research sample included 16 events (19.75\%) concerning people who were company shareholders. Each of these held more than $5 \%$ of the votes at the annual general meeting of shareholders.

We identified two dates for each event in the sample: the date of the actual event (event day, $e$ ) and the date on which the press release about the event was published (announcement day, a). Sometimes the two dates overlapped but, in most cases, there was a time difference of a few days (Figure 2).

Delays in publishing the announcements resulted primarily from the occurrence of non-trading days, such as weekends and holidays. By focusing on the date on which the company published the information, the measurement of investor reaction to the event of the death of a key person might be significantly distorted. The reaction on the event day might be different from the reaction on the announcement day ${ }^{1}$. Observed differences between the announcement day and the event day were the premise to expand the analysis using the date of any potential reaction, which we called the reaction day $(r)$.

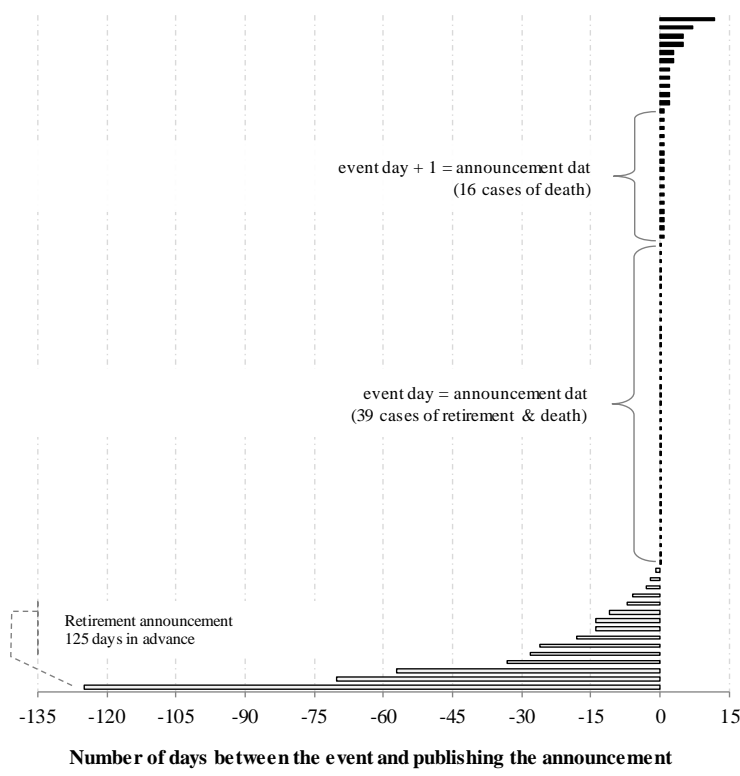

Figure 2. Distribution of Differences between the Event Day and the Announcement Day

Measurement of Investor Reactions. To examine the effects of the loss of a key person on market reactions, we use the standard event-study methodology (Brown \& Warner, 1985) to estimate cumulative abnormal return (CAR) and simple return (SR). Specifically, we estimated

announcements. If the event occurs after the close of trading on a particular day, the following day of trading in the company's shares is considered to be the date of the event. 
CAR for three different reference points: event day $\left(\mathrm{CAR}_{\mathrm{e}}\right)$, announcement day $\left(\mathrm{CAR}_{\mathrm{a}}\right)$ and reaction day $\left(\mathrm{CAR}_{\mathrm{r}}\right)$, but in each one it was for a two-day window:

$$
C A R_{i}=\sum_{t=t_{0}}^{t_{1}} A R_{i t}
$$

Where $C A R_{i}$ is the cumulative abnormal return over the observation window $[0,+1], A R_{i t}$ is the abnormal return for $i$ company on day $t$. In order to estimate the CAR we first estimate the expected return and the abnormal return $A R_{i t}$ on the basis of the market model:

$$
A R_{i}=R_{i t}-\widehat{\alpha}_{\imath}-\widehat{\beta}_{\imath} R_{m t}
$$

Where $R_{i t}$ represents the logarithmic returns shares for observation $i$ on day $t, R_{m t}$ defines the return on the market portfolio for day $t$. We use the WSE General Index (WIG) as a proxy for the market. To estimate the observation $\widehat{\alpha}_{\imath}$ and $\widehat{\beta}_{l}$ coefficients we followed earlier event studies (e.g., Nguyen \& Nielsen, 2008) using the period from 149 days to 1 day before the key person loss and ordinary least-squares (OLS) techniques.

Event studies have been widely used in earlier works to assess the consequences for shareholders of important discrete events such as the announcement of the loss of a key person (e.g., Salas, 2010, Betzer et al., 2020). However, as Peterson (1989) points out, event studies have their own weaknesses. One such is estimation of expected returns and adjustments returns by the market model. Therefore, we calculated $S R_{i}$, which served as an additional proxy of investor reaction. This solution is an essential simplification of the approximation of investor reactions as it does not take into account the difference in relation to the expected rate of return that is a derivate of current market changes, but it allows the capture of the direct impact of specified determinants on the direction of the reaction. Abnormal returns allow the assessment of the change of rate of return on shares compared with expected values, but do not allow us to report the real (upward or downward) direction of changes in share prices as a result of the event:

$$
S R_{i}=\ln \frac{R_{i t_{1}}}{R_{i t_{0}}}
$$

Where $R_{i t_{1}}$ is the share price one day after the event and $R_{i t_{0}}$ is the reference price. Conducting an analysis on the basis of a postulated reaction day requires a significant amount of work and the collection of a large amount of information (see Table 2), yet this type of analysis can provide a clue for investors implementing their strategies on the WSE. Due to its qualitative nature, the application of the reaction day can be done in the case of small populations, due to the amount of work.

Explanatory variables. The Tenure was used as the first explanatory variable to provide an entrenchment hypothesis impact of the loss of a key person on the market valuation of a listed company (model 2). The length of the key person's tenure was measured in years. Another proxy we used for entrenched executives is based on personal characteristic, i.e. Age of the key person (model 3). Finally, we additionally used an interactive variable between the dichotomous variable describing the type of event (retirement $=0$, death $=1)$ and Tenure $($ model 4$)$.
To measure the equity participation of a key person in the company, we employed three types of variables. The main explanatory variable is Shares, i.e. the percentage of shares held by the key person. Next, we create a dummy variable, Shareholder, which is coded 1 if the key person was holding shares in the investigated company at the time of the event, and 0 otherwise. Moreover, to identify the relative power of a key person in the decision-making process, we used Votes - the total number of votes, not just shares, held by the key person. Data were obtained from current and periodic reports.

Model specification. The analysis of determinants of the shareholders' reactions to the information about the loss of a key person was carried out on the basis of a linear multivariate regression. Similarly to Adamska \& Dabrowski (2016), we estimated the model parameters using the OLS method with robust standard errors. The analytical form of the econometric model used to test $\mathrm{H} 3$ is defined as:

$$
\begin{aligned}
& \text { CAR }_{(0 ;+1) i}= \\
& \alpha_{0}+\alpha_{1} \text { Tenure }_{i}+\alpha_{2} \text { Age }_{i}+\alpha_{3} \text { Death }_{i}+\alpha_{4} \text { Tenure }_{i} \times \text { Death }_{i}+ \\
& \sum_{m} \beta_{m} \text { Controls }_{m i}+\sum_{s} \gamma_{s} \text { Year }_{s i}+\varepsilon_{i}
\end{aligned}
$$

For the objective to develop a streamlined model to analyse the entrenchment hypothesis in the loss of a key person, we introduced four control variables ( Controls $_{m i}$ ). Specifically, to evaluate corporate governance quality, we include Board size, the number of supervisory board members of the company. In relation to Firm size, we argue that the loss of corporate talent likely has a stronger impact on stock prices of smaller companies, as they may find it harder to attract new (skilled) executives. Firm age - the number of years since the year of company establishment, is frequently used as a proxy of the organizational rigidities hypothesis. Finally, we use Shares, as a key person with substantial ownership power is susceptible to a self-serving bias can and can hold on to their position beyond their point of effectiveness (Boecker, 1992). Thus, we verify time fixed effects (Year) using dummy variables, one for each year of our sample period (i.e., 2005, 2006).

One potential concern with the cumulative abnormal returns is adjustments by the market model. Thus, our second empirical approach employs a logarithmic daily rate of return at event day. The adopted simple return models are the following:

$$
\begin{aligned}
& S R_{(0 ;+1) i}= \\
& \text { Model } 5 \quad \alpha_{0}+\alpha_{1} \text { Shareholder }_{i}+\sum_{m} \beta_{m} \text { Controls }_{m i}+ \\
& \sum_{s} \gamma_{s} \text { Year }_{s i}+\sum_{r} \gamma_{r} \text { Week }_{r i}+\varepsilon_{i} \\
& >6 \mathrm{pt} \\
& S R_{(0 ;+1) i}=\alpha_{0}+\alpha_{1} \text { Votes }_{i}+\sum_{m} \beta_{m} \text { Controls }_{m i}+ \\
& \text { Model } 6 \quad \sum_{s} \gamma_{s} \text { Year }_{s i}+\sum_{r} \gamma_{r} \text { Week } k_{r i}+\varepsilon_{i} \\
& >6 \mathrm{pt} \\
& S R_{(0 ;+1) i}=\alpha_{0}+\alpha_{1} \text { Shares }_{i}+\alpha_{2} \text { Index }_{i} \\
& \text { Models 7-9 } \quad \sum_{m} \beta_{m} \text { Controls }_{m i}+\sum_{s} \gamma_{s} \text { Year }_{s i}+\sum_{r} \gamma_{r} \text { Week }_{r i}+ \\
& \varepsilon_{i}
\end{aligned}
$$

In equations 5-7, Control represents the set of companylevel control variables. Some of them, such as Firm age and Board size have been discussed above, but we also included a natural logarithm of Market value as another measure of firm size. Year, like earlier, refers to year fixed effects, and Week is a count variable that takes on values between 1 and 7 for the announcements day of the week. 
Models 5-9 refer to the information about the impact of equity participation of the lost key person, while models 8 and 9 additionally take into account Index, the variable controlling investors' reaction to the market situation (i.e., the rate of return on the WIG) ${ }^{2}$. In models $1-8$, a criterion limiting trading volumes on the reaction day was introduced - they could not be lower than five shares. In model 9, this criterion was raised to ten shares. As a consequence, the sample was limited to 52 events.

Table 2

\section{Procedure for Determining the Rate of Return in the $[0,+1]$ Window for the Reaction Day}

\begin{tabular}{|c|c|c|c|}
\hline & & Reaction price $\left(t_{1}\right)$ & Reference price $\left(t_{0}\right)$ \\
\hline 1 & \multicolumn{3}{|c|}{ The announcement states the date and time of death: } \\
\hline 1.a & \multicolumn{3}{|c|}{ The date of death is a trading day: } \\
\hline 1.a.i & Death occurred before the start of trading & Opening price on the day of death & $\begin{array}{l}\text { Closing price on the trading day preceding } \\
\text { death }\end{array}$ \\
\hline 1.a.ii & Death occurred during trading & Closing price on the day of death & Opening price on the day of death \\
\hline 1.a.iii & Death occurred after the closing of trading & Opening price on the next trading day & Closing price on the day of death \\
\hline $1 . \mathrm{b}$ & Day of death is not a trading day & Opening price on the next trading day & Closing price on preceding trading day \\
\hline 2 & \multicolumn{3}{|c|}{ The announcement states only the day of death: } \\
\hline 2.a & \multicolumn{3}{|c|}{ The announcement is published on the day of death and it is a trading day: } \\
\hline 2.a.i & Announcement before the start of trading & $\begin{array}{l}\text { Opening price on the announcement day or } \\
\text { the first trading day following the } \\
\text { announcement }\end{array}$ & $\begin{array}{l}\text { Closing price on the trading day preceding } \\
\text { the announcement }\end{array}$ \\
\hline 2.a.ii & Announcement during trading & Closing price on the announcement day & Opening price on the announcement day \\
\hline 2.a.iii & Announcement after the closing of trading & Opening price on the next trading day & Closing price on the announcement day \\
\hline 2.b & $\begin{array}{l}\text { Announcement published on the day of death } \\
\text { and it is not a trading day }\end{array}$ & $\begin{array}{l}\text { Opening price on the first trading day after } \\
\text { the announcement }\end{array}$ & $\begin{array}{l}\text { Closing price on the trading day preceding } \\
\text { the announcement }\end{array}$ \\
\hline 2.c & $\begin{array}{l}\text { Announcement published after death and } \\
\text { event occurred on a trading day }\end{array}$ & $\begin{array}{l}\text { Opening price on the next trading day after } \\
\text { death }\end{array}$ & Closing price on the day of death \\
\hline $2 . \mathrm{d}$ & \multicolumn{3}{|c|}{ Announcement published after the death and event occurred on a non-trading day: } \\
\hline 2.d.i & $\begin{array}{l}\text { Announcement on the first day following the } \\
\text { event }\end{array}$ & $\begin{array}{l}\text { Opening price on the announcement day or } \\
\text { the first trading day after the announcement }\end{array}$ & $\begin{array}{l}\text { Closing price on the trading day preceding } \\
\text { death }\end{array}$ \\
\hline 2.d.ii & $\begin{array}{l}\text { Announcement on the next day following the } \\
\text { event }\end{array}$ & $\begin{array}{l}\text { Opening price on the first trading day } \\
\text { following the event }\end{array}$ & $\begin{array}{l}\text { Closing price on the trading day preceding } \\
\text { death }\end{array}$ \\
\hline 3 & \multicolumn{3}{|c|}{ The announcement does not state the date of death: } \\
\hline 3.a & \multicolumn{3}{|l|}{ Announcement published on a trading day } \\
\hline 3.a.i & Announcement before the start of trading & $\begin{array}{l}\text { Opening price on the announcement day or } \\
\text { the first trading day after the announcement }\end{array}$ & $\begin{array}{l}\text { Closing price on the trading day preceding } \\
\text { the announcement }\end{array}$ \\
\hline 3.a.ii & Announcement during trading & Closing price on the announcement day & Closing price on the announcement day \\
\hline 3.a.iii & Announcement after the close of trading & Opening price on the next trading day & Closing price on the announcement day \\
\hline 3.b & $\begin{array}{l}\text { Announcement published on a non-trading } \\
\text { day }\end{array}$ & $\begin{array}{l}\text { Opening price on the first trading day after } \\
\text { the announcement }\end{array}$ & $\begin{array}{l}\text { Closing price on the trading day preceding } \\
\text { the announcement }\end{array}$ \\
\hline
\end{tabular}

\section{Results}

We undertake the research objectives concerning shareholder reaction in multiple ways. In order to verify Hypothesis 1, the test for the average value of the CAR in the research window $[0,+1]$ was carried out for the entire research population $(N=73)$ and separately for events concerning deaths $(n=51)$ and old-age retirements $(n=22)^{3}$. The findings reported in Table 3 do suggest that shareholder reaction to the announcement of the death of a key person is negative and statistically significant, as in studies on CEO deaths (Johnson et al. 1985; Worrell et al., 1993; DhermentFerere \& Renneboog, 2002; Bennedsen et al., 2007; Nguyen \& Nielsen, 2010; Salas, 2010; Nguyen \& Nielsen, 2014; Brochet et al., 2015; Jenter et al., 2017). This is as we hypothesize (H1) and consistent with the upper echelon theory and corporate governance literature. The death of a key person caused a decrease in a company's value, on average, by $0.88 \%$ in relation to the reaction day $\left(\mathrm{CAR}_{\mathrm{r}}\right)$. This is confirmed by the average CAR for the event day $\left(\mathrm{CAR}_{\mathrm{e}}=-\right.$

\footnotetext{
${ }^{2}$ For models 5-9, the dependent variable is not a CAR, but a regular SR on shares at the closing of trading on the day following the reaction day. This solution is an essential simplification of the approximation of investor reaction as it does not take into account the difference in relation to the expected rate of return that is a derivate of current market changes, but it allows the capture of the direct impact of specified determinants on the direction of the reaction. Abnormal returns allow the assessment of the
}

$1.07 \%)$ and for the announcement day $\left(\mathrm{CAR}_{\mathrm{a}}=-0.50 \%\right)$. Thus, there are no grounds to reject the first hypothesis. The comparison of CAR in the $[0,+1]$ window for the reaction day proposed in this study, as well as for the event day and the announcement day, points to the existence of significant discrepancies between the mean values. For all reference points, the average CAR value does not exceed one percentage point, so the market's reaction can be considered relatively moderate. However, it is worth emphasizing the difference between the results for the day of publishing the announcement and the postulated reaction day. The average CAR calculated for the date of the announcement is twothirds lower than the CAR for the reaction day. In absolute values, it is only $0.657 \%$, yet it should be noted that this is an "excess" of return on shares above the theoretical return resulting from the market model.

The second hypothesis (H2) was tested on the basis of a test for two means in the subgroups of deaths and retirements, which were preceded by tests for equality of variances (Table 4). There is mixed evidence regarding the

change of the rate of return on shares compared with expected values, but these do not allow us to report the real (upward or downward) direction of changes in share prices as a result of the event.

${ }^{3}$ We excluded eight observations. In six cases the share price time series was too short to calculate market returns and two cases that occurred on the same day. 
nature of the studied phenomenon. A less negative investor reaction to the death of a key person was observed for the reaction day, compared with information about retirements. Meanwhile, the difference is positive for the announcement day $\left(\Delta \mathrm{CAR}_{\mathrm{a}}=0.68 \%\right)$ and the event day $\left(\Delta \mathrm{CAR}_{\mathrm{e}}=1.53 \%\right)$, which means that the average reaction of investors was in line with the adopted hypothesis. Moreover, $\triangle \mathrm{CAR}_{\mathrm{e}}$ was significantly different from zero $(\alpha=0.1)$. Although these findings are inconsistent with our second hypothesis (H2) regarding valuation effects of a sudden death, they support arguments present in literature regarding the effects of managerial entrenchment and power.
Table 3

Summary of the Value of Average CAR [0,+1]

\begin{tabular}{|c|c|c|}
\hline $\begin{array}{c}\text { All observations } \\
(\mathrm{N}=73)\end{array}$ & $\begin{array}{l}\text { Deaths } \\
(\mathrm{n}=51) \\
\end{array}$ & $\begin{array}{c}\text { Retirement } \\
(\mathrm{n}=22)\end{array}$ \\
\hline $\begin{array}{l}\text { Panel A: Reaction day } \\
\text { CAR }_{\mathrm{r}} \quad-0.95 \% * *\end{array}$ & $-0.88 \%{ }^{*}$ & $-1.13 \%{ }^{* *}$ \\
\hline $\begin{array}{l}\text { Panel B: Event day } \\
\mathrm{CAR}_{\mathrm{e}} \quad-0.61 \% *\end{array}$ & $-1.07 \%$ ** & $0.46 \%$ \\
\hline $\begin{array}{l}\text { Panel C: Announcement day } \\
\mathrm{CAR}_{\mathrm{a}} \quad-0.30 \%\end{array}$ & $-0.50 \%$ & $0.18 \%$ \\
\hline
\end{tabular}

Notes: The presented statistical significance of means is tested using the Student's t-test. *,**, and $* * *$ denote the significance of the parameter at $\alpha=0.1,0.05$, and 0.01 , respectively.

Table 4

Summary of Tests for Equality of Variances and Mean CAR $[0,+1]$ in the Subgroups for Death and Retirement

\begin{tabular}{|c|c|c|c|c|c|c|}
\hline & \multicolumn{3}{|c|}{ Test for equality of variances } & \multirow{2}{*}{$\begin{array}{c}\text { Difference of } \\
\text { means }\end{array}$} & \multicolumn{2}{|c|}{ Test for equality of means } \\
\hline & $F$-statistic & $p^{\dagger}$ & Conclusion & & $t$-statistic & $p^{\dagger \dagger}$ \\
\hline $\mathrm{CAR}_{\mathrm{r}}$ & 0.27 & 0.0017 & Significantly different & $-0.25 \%$ & -0.34 & 0.6324 \\
\hline $\mathrm{CAR}_{\mathrm{e}}$ & 0.88 & 0.7706 & Equal & $1.53 \%$ & $1.53^{*}$ & 0.0653 \\
\hline $\mathrm{CAR}_{\mathrm{a}}$ & 0.44 & 0.0444 & Significantly different & $0.68 \%$ & 0.84 & 0.2015 \\
\hline
\end{tabular}

Notes: ${ }^{\dagger}$ The p-value for the relations of variance is different from 1 (two-tailed test).

It The p-value for the difference of means is significantly greater than 0 (one-tailed test).

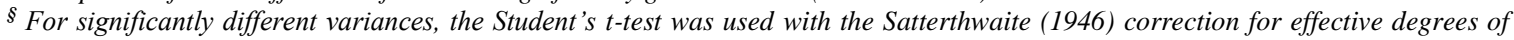

freedom. *, **, and *** denote the significance of the parameter at $\alpha=0.1,0.05$, and 0.01 , respectively.

The third hypothesis concerns the link between the ability of entrenched CEOs to persist regardless of their performance and shareholder wealth. To evaluate this effect, we include as regressors the variable Tenure and an interactive variable between Death and Tenure of the key person (model 4 in Table 5).

By directly interpreting the parameter of the interactive variable, we can conclude that the less time the key person held their position, the smaller the difference in the rate of return on shares and the WIG on the reaction day (Table 5). Investors, most likely, believe that such a situation entails an increase of risk. For each year that a key person holds a position, the abnormal rates of return are increased by 0.223 $\%$. The longer a given person remains within the company's organizational structure, the more positive the shareholders' reactions. This shows that investors are not concerned about the loss of well-established CEOs who potentially might have extraordinary knowledge of the industry. The results of the regression analysis in model 4 support the third hypothesis (H3) and arguments present in corporate governance literature regarding the effects of managerial entrenchment.

We test hypothesis four $(\mathrm{H} 4)$ regarding valuation effects of the loss of a key person with the inclusion of the participation in ownership structure variables. We observe that the coefficients of this variables are significantly negative in all tested models (Table 6). This implies that the greater the equity participation of a departing key person, the greater the effect of investor reaction on the Polish capital market. Hence, these findings are contrary to Slovin \& Sushka (1993) but they are consistent with hypothesis four (H4) and suggest that investor reactions are associated with the loss of a key person who had significant holdings in the company.

The results of the empirical analyses presented in this study confirm the existence of the phenomenon of a key person discount. However, it should be noted that the investor reactions were analysed across a very short time window. Taking into account the type of position held by the key person, we can observe that in the case of a person who is a member of the supervisory board, the discount is higher. These results are contrary to the assumption that it is the company's management board that bears the responsibility for the company's performance. It is also the management board that is criminally responsible in circumstances that violate the law.

The analysis of investor reactions in a very short onetrading-day window undoubtedly has its advantages, because of the need to isolate the impact of a specific event of the measured category. However, undoubtedly, the sudden loss of a key person in the company is a more complex situation that is worthy of further analysis. The Cumulative Abnormal Returns should be studied for the event day and the announcement day in a longer ten-day analysis window ${ }^{4}$ to further research in this field.

By isolating the two subgroups (i.e., death and retirement), it was concluded that regardless of the adopted reference point, the variable in the indicated event window had a negative change vector. Ten days after the event, the CAR values for death and retirement are similar $(-2.1 \%$ and $-2.4 \%$ on the tenth day). A possible explanation for this is that investors perceive both of these events, regardless of the cause, as the loss of a key asset of the company. The measurement for the announcement day progresses identically up until day eight. After this period the CAR for the event of a death returns to the value that preceded the event.

\footnotetext{
${ }^{4}$ The proprietary method of determining the moment of a potential reaction was based on just a one-day research window.
} 
Katarzyna Byrka-Kita, Mateusz Czerwinski, Renata Gola. Are the Key Persons in Companies Also Their Key Assets? ...

Table 5

Regression Model Explaining Cumulative Abnormal Returns for the Reaction Day

\begin{tabular}{|c|c|c|c|c|}
\hline Dependent variable: $\mathrm{CAR}_{\mathrm{r}}(0,+1)$ & Model 1 & Model 2 & Model 3 & Model 4 \\
\hline \multicolumn{5}{|l|}{ Explanatory variables } \\
\hline Tenure & & $\begin{array}{c}0.000256 \\
(0.39)\end{array}$ & & $\begin{array}{c}-0.00159 \\
(-1.12)\end{array}$ \\
\hline Age & & & $\begin{array}{c}-0.000241 \\
(-0.80)\end{array}$ & $\begin{array}{c}-0.000260 \\
(-0.75)\end{array}$ \\
\hline Death & & & & $\begin{array}{c}-\mathbf{0 . 0 1 5 9} 9^{* * *} \\
(-2.02)\end{array}$ \\
\hline Death * Tenure & & & & $\begin{array}{c}\mathbf{0 . 0 0 2 2 3}^{*} \\
(1.73) \\
\end{array}$ \\
\hline \multicolumn{5}{|l|}{ Controls } \\
\hline Board size & $\begin{array}{c}-\mathbf{- 0 . 0 0 2 9 7}^{* *} \\
(-2.15)\end{array}$ & $\begin{array}{c}-\mathbf{- 0 . 0 0 3 0 0}^{* *} \\
(-2.14)\end{array}$ & $\begin{array}{c}-\mathbf{0 . 0 0 3 3 3}^{* *} \\
(-2.56)\end{array}$ & $\begin{array}{c}-\mathbf{- 0 . 0 0 3 5 1}^{* *} \\
(-2.65)\end{array}$ \\
\hline Firm age & $\begin{array}{c}0.000125 \\
(1.25)\end{array}$ & $\begin{array}{c}0.000127 \\
(1.25)\end{array}$ & $\begin{array}{c}0.000135 \\
(1.32)\end{array}$ & $\begin{array}{c}0.000104 \\
(0.98)\end{array}$ \\
\hline Firm size & $\begin{array}{c}\mathbf{0 . 0 0 2 0 0}^{* *} \\
(2.13)\end{array}$ & $\begin{array}{c}\mathbf{0 . 0 0 2 0 3}^{* *} \\
(2.15)\end{array}$ & $\begin{array}{c}\mathbf{0 . 0 0 2 1 7}^{* *} \\
(2.41)\end{array}$ & $\begin{array}{c}\mathbf{0 . 0 0 2 2 0}^{* *} \\
(2.23)\end{array}$ \\
\hline Shares & $\begin{array}{c}-\mathbf{0 . 0 9 2 3} \\
(-5.29)\end{array}$ & $\begin{array}{c}-\mathbf{0 . 0 9 4 0} \\
(-5.57)\end{array}$ & $\begin{array}{c}-\mathbf{0 . 0 9 8 3}^{\text {**** }} \\
(-5.12)\end{array}$ & $\begin{array}{c}-\mathbf{0 . 0 9 4 1} \\
(-4.87)\end{array}$ \\
\hline Constant & $\begin{array}{c}-0.0123 \\
(-1.13)\end{array}$ & $\begin{array}{r}-0.0137 \\
(-1.18) \\
\end{array}$ & $\begin{array}{c}0.00182 \\
(0.09)\end{array}$ & $\begin{array}{r}0.0163 \\
(0.69) \\
\end{array}$ \\
\hline Year & Yes & Yes & Yes & Yes \\
\hline Number of observations & 73 & 73 & 73 & 73 \\
\hline$F$-statistic & 8.030 & 7.315 & 6.875 & 6.921 \\
\hline$R^{2}$ & 0.357 & 0.358 & 0.367 & 0.392 \\
\hline Adjusted $R^{2}$ & 0.173 & 0.160 & 0.171 & 0.158 \\
\hline
\end{tabular}

Notes: The equations were estimated using the OLS estimator. Standard errors are corrected for heteroscedasticity. Values of standard errors are shown in brackets. *, **, and $* * *$ denote the significance of the parameter at $\alpha=0.1,0.05$, and 0.01 , respectively.

\section{Conclusions}

This paper provides an empirical examination of the upper echelons theory and entrenchment hypothesis in a transitioning economy. Firstly, by analysing changes in shareholder value due to the deaths of incumbent members of top management teams, this paper has provided evidence that key persons are an important determinant of shareholder value for many firms.

While prior findings concerning the relationship between general directors and organizational performance are unclear or conflicting (Pitcher \& Smith, 2001; Cannella et al., 2008; Hambrick et al., 2015), we observed that the rates of return on shares decreased in response to the information about the death of a key person - shareholder reactions were negative and statistically significant. Even when the sample was divided into individual subgroups, the direction of change was always negative, and the characteristic of the analysed reaction did not change even when the event window was extended. These findings are consistent with the upper echelons theory. We fail to prove, however, that reactions to the news of the death of a key person are more negative than in the event of an age-related retirement on reaction day.
Secondly, we obtain interesting findings regarding the entrenchment hypothesis. The presence of a positive reaction to the loss of a so-called "entrenched CEO" has previously been confirmed in developed capital markets (Salas, 2010; Jenter et al., 2017). We also find that the longer a given person holds a position in a company, the more moderate the investor reactions are.

Finally, we evaluated the impact of equity connections on investor reactions associated with the publication of the loss of a key person. The stronger these connections were, the more pronounced the shareholder reactions were.

The analyses presented in this study are the first of their kind to be performed on data from a transition market. This paper contributes to a better understanding of investor reactions to organizational change events occurring in companies listed on the WSE. The results presented so far confirm that investors do take into account this type of event in investment strategies that they implement. Further, these results suggest that Polish firms need to undertake more formal succession planning for their executives.

Many questions still remain unanswered. One such involves the changes of financial results following the death of a key person. Thus, this area of research should be the subject of further analysis and discussion.

Table 6

Regression Model Explaining the Results of Simple Return for the Reaction Day

\begin{tabular}{|c|c|c|c|c|c|}
\hline Dependent variable: $\operatorname{SR}_{\mathrm{r}}(0,+1)$ & Model 5 & Model 6 & Model 7 & Model 8 & Model 9 \\
\hline \multicolumn{6}{|l|}{ Explanatory variables } \\
\hline Shareholder & $\begin{array}{c}-\mathbf{0 . 0 1 6 6}{ }^{*} \\
(-1.93)\end{array}$ & & & & \\
\hline Votes & & $\begin{array}{c}-\mathbf{0 . 1 0 0}^{* * * *} \\
(-4.28)\end{array}$ & & & \\
\hline Shares & & & $\begin{array}{c}-\mathbf{0 . 0 9 6 9} 9^{* * * *} \\
(-4.37) \\
\end{array}$ & $\begin{array}{c}-\mathbf{0 . 0 9 7 3} \\
(-4.28) \\
\end{array}$ & $\begin{array}{c}-\mathbf{0 . 1 1 2}^{* * * *} \\
(-5.32)\end{array}$ \\
\hline Controls & & & & & \\
\hline
\end{tabular}




\begin{tabular}{|c|c|c|c|c|c|}
\hline Dependent variable: $\operatorname{SR}_{\mathrm{r}}(0,+1)$ & Model 5 & Model 6 & Model 7 & Model 8 & Model 9 \\
\hline Market value & $\begin{array}{c}\mathbf{0 . 0 0 3 2 6}^{* * * *} \\
(2.88)\end{array}$ & $\begin{array}{c}\mathbf{0 . 0 0 3 4 4} \\
(3.18)\end{array}$ & $\begin{array}{c}\mathbf{0 . 0 0 3 4 2}^{* * * *} \\
(3.16)\end{array}$ & $\begin{array}{c}\mathbf{0 . 0 0 3 3 2}^{\text {**** }} \\
(3.07)\end{array}$ & $\begin{array}{c}\mathbf{0 . 0 0 3 8 1}^{* *} \\
(2.19)\end{array}$ \\
\hline Board size & $\begin{array}{c}-\mathbf{0 . 0 0 4 5 8}^{* * * *} \\
(-3.00)\end{array}$ & $\begin{array}{c}-\mathbf{0 . 0 0 4 4 7} 7^{\text {**** }} \\
(-3.13)\end{array}$ & $\begin{array}{c}-\mathbf{0 . 0 0 4 4 7 ^ { * * * * }} \\
(-3.14)\end{array}$ & $\begin{array}{c}-\mathbf{0 . 0 0 4 3 0} \\
(-3.19)\end{array}$ & $\begin{array}{c}-\mathbf{0 . 0 0 3 8 8}^{*} \\
(-1.91)\end{array}$ \\
\hline Firm age & $\begin{array}{c}\mathbf{0 . 0 0 0 1 3 8} \\
(1.45)\end{array}$ & $\begin{array}{c}\mathbf{0 . 0 0 0 1 5 5}^{*} \\
(1.68)\end{array}$ & $\begin{array}{c}\mathbf{0 . 0 0 0 1 5 7}^{*} \\
(1.70)\end{array}$ & $\begin{array}{c}0.000153 \\
(1.66)\end{array}$ & $\begin{array}{c}\mathbf{0 . 0 0 0 2 2 8}^{*} \\
(1.79)\end{array}$ \\
\hline Index & & & & $\begin{array}{l}0.158 \\
(0.54)\end{array}$ & $\begin{array}{c}\mathbf{0 . 7 1 8}^{* *} \\
(2.12)\end{array}$ \\
\hline Constant & $\begin{array}{c}-0.0242 \\
(-1.20) \\
\end{array}$ & $\begin{array}{c}-\mathbf{0 . 0 3 4 9} \\
(-1.84) \\
\end{array}$ & $\begin{array}{r}-\mathbf{0 . 0 3 4 3} \\
(-1.81) \\
\end{array}$ & $\begin{array}{c}-\mathbf{0 . 0 3 3 2}{ }^{*} \\
(-1.75) \\
\end{array}$ & $\begin{array}{c}-\mathbf{0 . 0 5 7 2}^{*} \\
(-1.95)\end{array}$ \\
\hline Week & Yes & Yes & Yes & Yes & No \\
\hline Year & Yes & Yes & Yes & Yes & Yes \\
\hline Number of observations & 73 & 73 & 73 & 73 & 52 \\
\hline$F$-statistic & 3.023 & 4.613 & 4.677 & 4.158 & 6.676 \\
\hline$R^{2}$ & 0.577 & 0.604 & 0.598 & 0.601 & 0.598 \\
\hline Adjusted $R^{2}$ & 0.402 & 0.441 & 0.433 & 0.425 & 0.397 \\
\hline
\end{tabular}

Notes: The equations were estimated using the OLS estimator. Standard errors are corrected for heteroscedasticity. Values of standard errors are shown in brackets. *, **, and $* * *$ denote the significance of the parameter at $\alpha=0.1,0.05$, and 0.01 , respectively.

\section{Acknowledgements}

We thank the anonymous referees for helpful comments and suggestions. This research is supported by funds from the National Science Centre: project title: Company's market value and financial performance versus CEO succession, agreement No. 2014/15/B/HS4/04355, head: Katarzyna Byrka-Kita.

\section{References}

Adamska, A., \& Dabrowski, T. J. (2016). Do investors appreciate information about corporate social responsibility? Evidence from the Polish equity market. Inzinerine Ekonomika/Engineering Economics, 27(4), 364-372. https://doi.org/10.5755/j01.ee.27.4.13377

Bennedsen, M., Perez-Gonzalez, F., \& Wolfenzon, D. (2007). Do CEOs Matter?. Working paper, Copenhagen Business School. http://dx.doi.org/10.2139/ssrn.970575.

Betzer, A., Lee, H. S., Limbach, P., \& Sales, J. M. (2020). Are Generalists Beneficial to Corporate Shareholders? Evidence from Exogenous Executive Turnovers. Journal of Financial and Quantitative Analysis, 55(2), 581-619. http://dx.doi.org/10.2139/ssrn.2939486.

Boeker, W. (1992), Power and managerial dismissal: Scapegoating at the top. Administrative Science Quarterly, 37(3), 400421. https://doi.org/10.2307/2393450.

Brochet, F., Limbach, P., Schmid, M., \& Scholz-Daneshgari, M. (2015). All Good Things Come to an End: CEO Tenure and Firm Value. Paper presented at the 19th Annual Conference of the Swiss Society for Financial Market Research (SGF), Zurich. http://dx.doi.org/10.2139/ssrn.2626340.

Brown, S. J. \& Warner, J. B. (1985). Using daily stock returns: The case of event studies. Journal of Financial Economics, 14(1), 3-31. https://doi.org/10.1016/0304-405X(85)90042-X.

Buoziute-Rafanaviciene, S., Pundziene, A., \& Turauskas, L. (2009). Relation between the attributes of executive successor and organizational performance. Inzinerine Ekonomika-Engineering Economics, 62(2), 65-74. http://inzeko.ktu.lt/index.php/EE/article/view/11625/6307.

Campbell, K., \& Vera, A. M. (2010). Female board appointments and firm valuation: short and long-term effects. Journal of Management and Governance, 14(1), 37-59. https://doi.org/10.1007/s10997-009-9092-y.

Cannella, A. A., Park, J. H., \& Lee, H. U. (2008). Top Management Team Functional Background Diversity and Firm Performance: Examining the Roles of Team Member Colocation and Environmental Uncertainty. Academy of Management Journal, 51(4), 768-784. https://doi.org/10.5465/amr.2008.33665310.

Daszynska-Zygadlo, K., Ryszawska, B., Slonski, T., \& Zawadzki, B. M. (2014). Investors' reactions for sustainability index inclusion-is CSR a good news? Acta Universitatis Lodziensis. Folia Oeconomica, 2(300), 45-60.

Davidson, W. N., Worell, D. L., \& Cheng, L. (1990). Key executive succession and stockholder wealth: The influence of successors origin, Position, and Age, Journal of Management, 16(3), 647-664. https://doi.org/10. 1177/014920639001600309

Denis, D. J., \& Denis, D. K. (1995). Firm performance changes following top management dismissals, Journal of Finance, 50(4), 1029-1057. https://doi.org/10.1111/j.1540-6261.1995.tb04049.x.

Dherment-Ferere, I., \& Renneboog, L. (2002). Share Price Reactions to CEO Resignations and Large Shareholder Monitoring in Listed French Companies. In: J. McCahery, L. Renneboog, P. W. Moerland and T. Raaijmakers (eds.), 
Katarzyna Byrka-Kita, Mateusz Czerwinski, Renata Gola. Are the Key Persons in Companies Also Their Key Assets? ...

Corporate Governance Regimes: Convergence and Diversity. Oxford: Oxford University Press, 297-324, (working paper version available at http://dx.doi.org/10.2139/ssrn.244678).

Elsaid, E., Wang, X., \& Davidson, W. N. (2011). Does experience matter? CEO successions by former CEOs, Managerial Finance, 73(10), 915-939. https://doi.org/10.1108/03074351111161583.

Farrell, K. A., \& Hersch, P. L. (2005). Additions to corporate boards: The effect of gender, Journal of Corporate Finance, 11(1-2), 85-106. https://doi.org/10.1016/j.jcorpfin.2003.12.001.

Gomulya, D., \& Boeker, W. (2014). How firms respond to financial restatement: CEO successors and external reactions, Academy of Management Journal, 57(6), 1759-1785. https://doi.org/10.5465/amj.2012.0491.

Gurgul, H., Mestel, R., \& Schleicher, C. (2003). Stock market reactions to dividend announcements: Empirical evidence from the Austrian stock market. Financial Markets and Portfolio Management, 17(3), 332-350. https://doi.org/10.1007/s11408-003-0304-1.

Hambrick, D. C., Humphrey, S. E., \& Gupta, A. (2015). Structural Interdependence within Top Management Teams: A Key Moderator of Upper Echelons Predictions. Strategic Management Journal, 36(3), 449-461. https://doi.org/10.1002/smj.2230.

Hambrick, D. C., \& Mason, P. A. (1984). Upper echelons: The organization as a reflection of its top managers, Academy of management review, 9(2), 193-206. https://doi.org/10.5465/amr.1984.4277628

Hamori, M., \& Koyuncu, B. (2015). Experience matters? The impact of prior CEO experience on firm performance. Human Resource Management, 54(1), 23-44. https://doi.org/10.1002/hrm.21617.

Huang, H. H., Hsu, P., Khan, H. A. \& Yu, Y. L. (2008). Does the appointment of an outside director increase firm value? Evidence from Taiwan. Emerging Markets Finance and Trade, 44(3), 66-80. https://doi.org/10.2753/REE1540$496 \times 440305$

Ishak, R., \& Latif, R. (2013). June. CEO succession: is it good or bad news. In Proceedings of 7th global business and social science research conference (1-18).

Ismail, K. N. I. K., \& Manaf, K. B. A. (2016). Market reactions to the appointment of women to the boards of Malaysian firms. Journal of Multinational Financial Management, 36, 75-88. https://doi.org/10.1016/j.mulfin.2016.04.004.

Jensen, M. and Meckling, W. (1976). Theory of the firm: Management behavior, agency costs and capital structure. Journal of financial economics, 3(4), 305-60. https://doi.org/10.1016/0165-4101(85)90034-5.

Jenter, D., Matveyev, E. \& Roth, L. (2017). Good and Bad CEOs. Working Paper, London School of Economics, https://cepr.org/sites/default/files/5650_JENTER - Good and Bad CEOs.pdf.

Johnson, W. B., Magee, R. P., Nagarajan, N. J., \& Newman, H. A. (1985). An analysis of the stock price reaction to sudden executive deaths: Implications for the managerial labor market. Journal of Accounting and Economics, 7(1-3), 151-174.

Kaplan, S. N., Klebanov, M. M., \& Sorensen, M. (2012). Which CEO characteristics and abilities matter? The Journal of Finance, 67(3), 973-1007. https://doi.org/10.1111/j.1540-6261.2012.01739.x.

Lee, J. M., Kim, J., \& Bae, J. (2020). Founder CEOs and innovation: Evidence from CEO sudden deaths in public firms. Research Policy, 49(1). https://doi.org/10.1016/j.respol.2019.103862.

Malmendier, U., \& Tate, G. (2009). Superstar CEOs, The Quarterly Journal of Economics, 124(4), 1593-1638. https://doi.org/10.1162/qjec.2009.124.4.1593.

Nguyen, B. D., \& Nielsen, K. M. (2010). The Value of independent directors: Evidence from sudden deaths, Journal of Financial Economics, 98(3), 550-67. https://doi.org/10.1016/j.jfineco.2010.07.004.

Nguyen, B. D., \& Nielsen, K. M. (2014). What Death Can Tell: Are Executives Paid for Their Contributions to Firm Value?. Management Science, 60(12), 2994-3010. https://doi.org/10.1287/mnsc.2014.2011.

Ocasio, W. (1994). Political dynamics and the circulation of power: CEO succession in US industrial corporations, 19601990. Administrative science quarterly, 285-312. https://www.jstor.org/stable/2393237.

Pessarossi, P., \& Weill, L. (2013). Does CEO turnover matter in China? Evidence from the stock market. Journal of Economics and Business, 70, 27-42. https://doi.org/10.1016/j.jeconbus.2013.04.003

Peterson, P. P. (1989). Event studies: A review of issues and methodology. Quarterly Journal of Business and Economics, 28(3), 36-66. https://www.jstor.org/stable/40472954

Pitcher, P., \& Smith, A. D. (2001). Top Management Team Heterogeneity: Personality, Power, and Proxies. Organization Science, 12(1), 1-18. https://doi.org/10.1287/orsc.12.1.1.10120.

Pundziene, A., \& Duobiene, J. (2006). CEOs' entrepreneurship in relation to reaction to organizational change. Engineering Economics, 47(2), 91-98. http://inzeko.ktu.lt/index.php/EE/article/view/11351

Salas, J. M. (2010). Entrenchment, Governance, and the Stock Price Reaction to Sudden Executive Deaths. Journal of Banking and Finance, 34(3), 656-666. http://dx.doi.org/10.2139/ssrn.819564.

Satterthwaite, F. (1946). An Approximate Distribution of Estimates of Variance Components. Biometrics Bulletin, 2(6), 110-114. http://dx.doi.org/10.2307/3002019. 
Selznick, P. (1957). Leadership in Administration. A Sociological Interpretation. Evanston, Illinois, Row, Peterson and Company.

Setiawan, D., Hananto, S. T., \& Kee, P. L. (2011). An analysis of market reaction to chief executive turnover announcement in Indonesia: A Trading Volume Approach. Journal of Business \& Economics Research (JBER), 9(11), 63-72. https://doi.org/10.19030/jber.v9i11.6501

Shleifer, A., \& Vishny, R.W. (1989). Management entrenchment: The case of manager-specific investments. Journal of financial economics, 25(1), 123-139. https://doi.org/10.1016/0304-405X(89)90099-8.

Slovin, M., \& Sushka, M. (1993). Ownership Concentration, Corporate Control Activity, and Firm Value: Evidence from the Death of Inside Blockholders. The Journal of Finance, 48(4), 1293-1321. http://doi.org/10.2307/2329039

Weisbach, M. S. (1988). Outside directors and CEO turnover. Journal of financial Economics, 20, $431-460$. https://doi.org/10.1016/0304-405X(88)90053-0.

Worrell, D. L., Davidson III, W. N., \& Glascock, J. L. (1993). Stockholder reactions to departures and appointments of key executives attributable to firings. Academy of Management Journal, 36(2), 387-401. https://doi.org/10.5465/256528.

Zhang, Y. (2015). How Does Untimely Death of an Executive Affect Stock Prices and Company Performance? All Graduate Plan B and other Reports, 454, https://digitalcommons.usu.edu/gradreports/454.

The article has been reviewed.

Received in May 2019; accepted in December 2020.

This article is an Open Access article distributed under the terms and conditions of the Creative Commons Attribution 4.0 (CC BY 4.0) License (http://creativecommons.org/licenses/by/4.0/). 